\title{
Cellular growth and function
}

By Elsie M. Widdowson, Department of Medicine, University of Cambridge, Cambridge

A great deal has been written in recent years about the effect of nutrition on the growth and multiplication of cells. Although the foundations had been laid down before 1965 , it was the publication of several papers by Winick \& Noble (1965, 1966, 1967) that aroused the interest of the nutrition world in the subject. Winick \& Noble (1965) described cellular development of the lean parts of the body in three stages. Firstly the organ grows by hyperplasia, that is by an increase in the number of cells without any appreciable increase in their average size. Secondly the cells begin to increase in size or hypertrophy before they divide. Then at a certain time for each organ and each species cell division stops, and subsequent growth is due entirely to an increase in size of the cells already there. When this process also ceases growth of the organ is over. If cell division in an organ is slowed down or stopped by undernutrition when it should be proceeding rapidly, the organ may not be able to complete its cell population within the time at its disposal, so the adult may finish up with too few cells in its organs, and in its body as a whole (Winick \& Noble, 1966).

More recently interest has centred on the fat cells and the adipose organ so called. Overnutrition in early life is said to be an important cause of obesity later, and it has been suggested that this is because it speeds up the multiplication of fat cells in infancy so that the older child and adult finish up with too many. This implies that for each species and age there is an optimum number of cells in both lean and adipose organs and in the brain. In the internal organs and brain a small number of cells is assumed to confer a disadvantage, whereas in the adipose organ it is the large number which does the same thing. It is true that the more cells there are in an organ the larger it is likely to be, but size is not everything, even in brains, and we must take genetics into account as well as nutrition. Human beings vary a great deal in their heights and weights at any given age, even though they are all being given plenty of good food. One would expect small bodies to have small organs, and whenever we make the necessary measurements we find that the size of the hearts, kidneys, lungs and other organs of the well-nourished person or animal are the right size for the body as a whole. The small kidneys in a genetically small individual are perfectly capable of maintaining the constancy of the volume and composition of his body fluids, even though, taken out of the body and analysed, they might be condemned as having too few cells.

In the old days anyone who wanted to know anything about the cellular makeup of a tissue looked at a stained section of it under a microscope. However, measuring and counting cells from a microscope slide on a grid is a very laborious 
business, though it still remains the only method for finding the number of cells in skeletal muscle and is probably still the best method for adipose tissue. The biochemists devised something much quicker, but it involved smashing up the tissue so that all the cell walls were broken down and the chemical reagents could get at the contents of the nuclei, including the DNA, and react with it so that it could be measured. All the diploid nuclei of a given animal species contain the same amount of DNA, and this is $6 \mathrm{pg}$ for man. If, therefore, we determine the amount of DNA in an organ or tissue which has mononuclear cells with only diploid nuclei within them, we can calculate the number of nuclei and, hence, of cells in the organ. If we also measure the protein we can then use the ratio of protein to DNA, or amount of protein per nucleus, as an index of the average size of the cells. We can also measure RNA, which is responsible for protein synthesis within the cell, and this gives a more dynamic approach to cellular growth than the measurement of protein that is already there. The speed with which determinations of DNA, RNA and protein can be made has enabled us to learn a great deal about the quantitative side of cellular growth and multiplication which we should never have been able to get with a microscope. On the other hand, this method tells us nothing about the different types of cells within an organ, and how these vary in size, structure and function. The cells of the liver, kidney and pancreas, for example, and above all, the brain, are functionally highly differentiated, but a measurement of DNA gives no clue about this or how the different structures within the organ develop and begin to function. I believe that the importance of having a large number of cells in our internal organs and a small number in our adipose tissue has been over-emphasized. We must be very careful in drawing conclusions about the efficiency of an organ, either infant or adult, from an analysis of the number of cells in it, without considering its size, structure and performance relative to the body from which it came.

I could take many different organs to illustrate my point, and I have chosen the kidney. Widdowson, Crabb \& Milner (1972) measured the total amount of DNA in the two kidneys of each of 59 human foetuses between 13 weeks gestation and term. Five pairs of kidneys came from babies that were small for their gestational age. Cell division is always most rapid in the early stages of development and this phase had already passed before this study began. By 14 weeks gestation the two kidneys between them already contained over I mg DNA, or the amount in the nuclei of about 200 million cells. Five further divisions and redivisions were required to bring the amount of DNA to $40 \mathrm{mg}$ at 26 weeks gestation and perhaps one more division to arrive at the amount at term. The five pairs of kidneys from foetuses small for their gestational age all had fewer cells in their kidneys than the lowest number for the supposedly normal ones, but they also had smaller bodies and smaller kidneys. Even among normal foetuses, however, there was often one with twice as much DNA and, therefore, presumably twice as many cells in its kidneys as those of another of the same gestational age. This only means that those with more cells were one cell division ahead of the others. The foetal period is a highly dynamic one in the growth of the organs, and there is no reason to 
suppose that the foetus with fewer cells in its kidneys at any given gestational age will be any the worse off in the long run than the foetus with more numerous ones.

When we come to the adult there is also a wide variation in the amount of DNA in the organs from one individual to another. In the adult, however, the bigger the body the bigger the organ, and on the whole the bigger the organ the more cells in it, but this was not necessarily true in the active period of cell division before birth.

Other organs show just as much variation as the kidneys. Dobbing \& Sands (1973) measured the total amount of DNA-phosphorus in the human forebrain during foetal life, right through childhood and on into maturity. Cell division does not begin to draw to a close until well into the second year, but their results show one child of 2 years with only half as much DNA in its forebrain as another. The adult forebrain varied nearly as much. It was the large brains that had most DNA but I would like to emphasize, and I know Dr Dobbing agrees, that apart from disease there is no evidence of any relationship whatever between mental ability and the size of the brain or the number of cells in it.

The time of life when the most dramatic change in function occurs is at or just after birth. Within minutes of being delivered the newborn infant or animal must breathe, expand its lungs and reroute its circulation. This done, the next requirement is to take in food and water and arrange for the disposal of the waste products. This calls into play organs which have not hitherto had a great deal to do, notably those concerned with digestion and excretion. Morphological studies of the development of the human kidney show that by 8 weeks gestation the nephrons of the metanephros or true kidney begin to develop, and the number of nephrons is complete by term (Potter \& Thierstein, 1943). The glomeruli are about half the adult size and the tubules too are short and not completely differentiated. However they are all there, about 82000 of them in each kidney by the time the baby is born, although the cells have only reached about $20 \%$ of the adult number. Does the small for dates baby have too few nephrons? I do not know, but that seems much more important functionally than the number of cells. The cells change in size and shape after birth, particularly those of the semipermeable membranes of the glomerular capillaries which are concerned with the filtration of the blood. It is as a result of these changes that the ability of the infant to concentrate its urine develops and hence its ability to excrete sodium and other substances (Edelman \& Spitzer, 1976).

We have recently been studying the response of the digestive and other organs of newborn piglets to feeding after birth (Widdowson \& Crabb, 1976; Widdowson, Colombo \& Artavanis, 1 976). We used 45 piglets from ro litters. Some of each litter were killed at birth, without being allowed to feed. Others were allowed to feed from the mother for $24 \mathrm{~h}$, and a third group was given water by stomach tube at intervals, but no food. The piglets receiving food or water were killed after $24 \mathrm{~h}$. A fourth group was suckled by the mother for ro $d$ and then killed. We had already taken foetuses from 4 litters $20 \mathrm{~d}$ before term (Widdowson, 1971).

The small intestine of the suckled piglets increased in weight by $60 \%$ during the first $24 \mathrm{~h}$ after birth, but there was a loss in weight in those given only water. This 
growth in response to food was due largely to an increase in weight of the mucosa. The suckled piglets themselves gained weight, and their kidneys grew particularly rapidly in the $24 \mathrm{~h}$ after birth. In fact they gained more weight in one day after birth than they did in the last $20 \mathrm{~d}$ before birth. Table I shows that they did this primarily by a rapid incorporation of protein into existing cells, though there was also some increase in DNA. Before birth in the piglet growth of the kidneys had been primarily by an increase in cell number, not by an increase in cell size, as measured by the protein to DNA ratio. The rapid changes just after birth were part of the kidney's expanding function, and can be thought of teleologically as secondary to the development of the gastrointestinal tract and the absorption of nutrients through it. The growth of the human kidney just after birth is due mainly to a rapid increase in length and volume of the proximal tubules. This may be true also of the pig but, whether that is so or not, development of the kidney before birth has made it ready to take on its function of maintaining the volume and composition of the body fluids after birth, and its immediate response to functional demand is an increase in the size of the cells rather than an increase in their number.

Table I. Weight and composition of the kidneys of foetal and newborn pigs

$\begin{array}{lccccc} & \begin{array}{c}\text { Foetus } \\ 24 \text { d before } \\ \text { term }\end{array} & \begin{array}{c}\text { At birth } \\ \text { unfed }\end{array} & \overbrace{\text { Unfed }} & \text { Suckled } & \begin{array}{r}\text { Iod } \\ \text { suckled }\end{array} \\ \text { Weight 2 kidneys (g) } & 4.43 & 7.21 & 6.72 & 10.2 & 23.7 \\ \begin{array}{l}\text { Protein (mg) } \\ \text { DNA (mg) }\end{array} & 303 & 653 & 668 & 953 & 2237 \\ \text { Protein (mg) } & 29.1 & 58.4 & 53.8 & 68.6 & 99.3 \\ \text { DNA (mg) } & 10.5 & 11.7 & 12.4 & 14.2 & 23.0\end{array}$

I will conclude with a few words about the fat tissues of the body, and particularly the number and size of fat cells. The human infant is exceptional among mammals in that it has a considerable store of fat in its white adipose tissue at birth (Widdowson, 1950). Many species have practically no fat when they are born, but they begin to deposit fat directly they start feeding, and they may lay down astonishing quantities. Even the healthy human baby increases its fat more rapidly than its lean body tissues, so that by the time the weight has doubled the fat has trebled (Fomon, 1974). Brook's (1972) results suggests that there is a threefold increase in the number of cells containing fat in the first year after birth, and a fivefold increase between one and thirteen years. Brook has suggested that the last 10 weeks of normal gestation and the first year after birth are a sensitive period for fat cell replication in man. Overnutrition during this time, he suggested, leads to more rapid multiplication of fat cells and this is an important cause of later obesity.

But there are problems. Dauncey \& Gairdner's (1975) work shows that the mean fat cell size is not the same all over the body, so a biopsy from one site may not be representative of all adipose tissue. In the term infant, for example, cells in the gluteal region average $68 \mu \mathrm{m}$ diameter and those in the anterior abdominal wall $50 \mu \mathrm{m}$. Because of the relation between the diameter of a sphere and its volume the 
amount of fat in a cell differs much more than its diameter. The cells in these two sites contained 0.17 and $0.06 \mu \mathrm{g}$ of fat respectively. There was a doubling of the diameter of the average cell in the abdominal wall during the 7-10 months after birth, and a tenfold increase in the amount of lipid per cell. If there is the same increase in cell volume in other parts of the body there is no need for multiplication of fat cells to accommodate the fat laid down in the body during the first ro months after birth.

Some, but not all, obese children and adults appear to have more fat cells than lean individuals (Hirsch \& Knittle, 1970; Brook, Lloyd \& Wolff, 1972; Salans, Cushman \& Weismann, 1973) but, since only cells containing a certain minimum amount of fat can be measured and counted, it is equally possible that obese persons have a greater proportion of their adipose cells with enough fat in them to be recorded. On the other hand a thin individual may have millions of fat cells which would never appear in an adipose cell count, but are ready to be filled if the intake of energy becomes greater than the expenditure, and the capacity for storage of energy in cells already containing fat is exhausted.

This is even more true of an undernourished person or animal. Severely undernourished animals and children have no measurable subcutaneous or deep body fat at all, and the connective tissue where the fat cells ought to be presents as a watery gel. Fat cells are completely empty and do not register by any method of counting. As soon as plentiful food is supplied the empty cells begin to fill up with fat and all the evidence goes to show that previously undernourished individuals, be they children or young animals, become fat when they are rehabilitated, fatter than those that have never been undernourished, and the longer the period of deprivation and the more severe it has been the fatter they become. We do not know whether they do this by multiplying their fat cells or filling up those they already have. Either way it looks as though it is not only the overfed infant that is booked to be a fat child and adult; the rehabilitated underfed one may be heading the same way.

The difficulty of detecting empty cells by any of the usual methods of counting fat cells makes it unwise to say much about changes in numbers of fat cells during normal growth, or the development of obesity. In fact there seems no real evidence that there is any increase in the number of fat cells in the human baby after birth, particularly if one includes the differentiated precursors or preadipocytes which have the potential for developing into mature fat cell types. The number of fat cells probably varies from one individual to another and it may be determined genetically. At what stage in life it can be influenced by the nutritional environment still remains to be discovered.

\section{REFERENCES}

Brook, C. D. G. (1972). Lancet ii, 624.

Brook, C. D. G., Lloyd, J. K. \& Wolff, O. H. (1972). Br. med. Y. ii, 25.

Dauncey, M. J. \& Gairdner, D. M. T. (1975). Archs Dis. Childh. 50, 286.

Dobbing, J. \& Sands, J. (1973). Archs Dis. Childh. 48, 757.

Edelman, C. M. \& Spitzer, A. (1976). In The Physiology of the Newborn Infant, p. $4^{16}$ [C. A. Smith \& N. M. Nelson, editors]. Springfield, Ill.: C. C. Thomas. 
Fomon, S. J. (1974). Infant Nutrition, 2nd ed. Philadelphia: W. B. Saunders.

Hirsch, J. \& Knittle, J. L. (1970). Fedn Proc. Fedn Am. Socs exp. Biol. 29, 1516.

Potter, E. L. \& Thierstein, S. T. (1943). F. Pediat. 22, 695.

Salans, L. B., Cushman, S. W. \& Weismann, R. E. (1973). J. clin. Invest. 52, 929.

Widdowson, E. M. (1950). Nature, Lond. 166, 626.

Widdowson, E. M. (1971). Biol. Neonate 19, 329.

Widdowson, E. M., Colombo, V. E. \& Artavanis, C. A. (1976). Biol. Neonate 28, 272.

Widdowson, E. M. \& Crabb, D. E. (1976). Biol. Neonate 28, $26 \mathrm{r}$.

Widdowson, E. M., Crabb, D. E. \& Milner, R. D. G. (1972). Archs Dis. Childh. 47, 652.

Winick, M. \& Noble, A. (1965). Devel Biol. 12, 451 .

Winick, M. \& Noble, A. (1966). F. Nutr. 89, 300 .

Winick, M. \& Noble, A. (1967). F. Nutr. 9I, 179. 